Article

\title{
Understanding Consumers' Sustainable Consumption Intention at China's Double-11 Online Shopping Festival: An Extended Theory of Planned Behavior Model
}

\author{
Shuai Yang * (D), Lei Li and Jiemin Zhang \\ Glorious Sun School of Business and Management, Donghua University, Shanghai 200051, China; \\ 2171052@mail.dhu.edu.cn (L.L.); zhangiiemin123@126.com (J.Z.) \\ * Correspondence: shuai.yang@dhu.edu.cn
}

Received: 8 May 2018; Accepted: 29 May 2018; Published: 30 May 2018

\begin{abstract}
Double-11 shopping festival has become the largest national shopping festival in China. This study investigates the effect of the atmosphere during the Double-11 shopping festival on Chinese people's sustainable consumption by extending the Theory of Planned Behavior (TPB). A survey on a sample of 404 Chinese consumers showed that the atmosphere specific to China's Double-11 shopping festival was negatively associated with consumers' purchase intention toward sustainable consumption. Moreover, the negative relationship was mediated by consumers' attitude toward sustainable consumption, the subjective norm, and perceived behavioral control.
\end{abstract}

Keywords: sustainable consumption behavior; double-11 online shopping festival; planned behavior model; atmosphere

\section{Introduction}

China, as a developing country with the largest population in the world, is one of the largest economies in Asia. However, the rapid economic growth in China has resulted in adverse environmental degradation via over-consumption. In recent years, Chinese people have become increasingly concerned about environmental degradation [1]. Researchers have indicated that consumers' willingness to engage is key to sustainable consumption [2]. Thus, many studies have focused on how to motivate Chinese consumers to engage in sustainable consumption [3].

However, most research has focused on Chinese people's sustainable consumption behaviors for regular purchases, while ignoring extraordinary situations, such as China's Double-11 online shopping festival. The Double-11 shopping festival was founded in 2009, where Taobao offered huge discounts on 27 participating brands' websites on November 11 to boost its sales. In 2016, nearly 40,000 brands with more than 8,000,000 products from 1562 categories (e.g., appeals, cosmetics, dairy products, electrical appliances) were involved in the Double-11 shopping festival, and more than 20,000 brands offered $50 \%$ discounts [4]. Within the following couple of years, the Double- 11 shopping festival successfully turned into a national shopping festival in China, which is similar to Black Friday in the United States [5]. The economic benefits carried out by the festival have increased year by year [6]. For example, the trading volume reached more than 14 billion dollars on 11 November 2015, which was a $159.71 \%$ increase in volume from 11 November 2014.

Given that festive occasions are always associated with over-consumption [7], it is important to examine Chinese people's sustainable consumption behaviors during the Double-11 shopping festival. The prevailing shopping atmosphere during this highly festive period may affect people's sustainable consumption behaviors [8]. 
The Theory of Planned Behavior (TPB) has been used widely in previous research to investigate the motivation of sustainable consumption intentions [9], but has not considered the impacts of a festival atmosphere. Given that the consumption context might have effects on consumers' purchase intention and behaviors [10], it is of value to sustainable marketing to investigate the effect of the atmosphere during the Double-11 shopping festival on Chinese people's sustainable consumption intention by extending the Theory of Planned Behavior (TPB) [9]. Therefore, this study aims: (1) to examine the effect of atmosphere (specifically China's Double-11 Shopping Festival atmosphere) on consumers' sustainable consumption intention; (2) to provide a deeper understanding of the link between environmental concern and sustainable consumption intention in the TPB within the context of China's Double-11 shopping festival; and (3) to examine the moderating effect of consumer characteristics on the relationships between variables in the extended TPB framework. The study uses a structural equation model to estimate these relationships.

This study proceeds as follows. First, the study reviews the literature on sustainable consumption, the TPB model, and atmosphere, and proposes the hypothesis. Second, this study describes the methodology, including the sample, data collection, and measures. After presenting the results, this study discusses the theoretical and managerial implications, as well as the limitations and future research.

\section{Literature Review}

\subsection{Sustainable Consumption}

The term "sustainable consumption" can be traced back to the call for "Reduction of Unsustainable Patterns of Production and Consumption" in the United Nations Conference on Environment and Development in 1992 [11]. Later, in 1994, the Oslo Symposium on Sustainable Consumption organized by the Norwegian government defined sustainable consumption as "the use of goods and services which satisfy the basic needs and enable a better life quality and at the same time the minimization of the consumption of natural resources, the generation of toxic materials and waste and pollutants over a life cycle, so that there is no risk of the impossibility to satisfy the needs of future generations" [12] (p. 2).

While there is a general agreement that sustainable consumption is desirable and important [13], it is notable that positive attitudes on sustainable consumption might not turn into actual sustainable consumption behaviors [14]. Thus, the main agenda of sustainable consumption is to incentivize consumers to purchase green products and maximize the sales of green products in the short run, while encouraging consumers to adopt an environmentally friendly lifestyle such as buying less and buying better in the long run [15-17].

\subsection{Theory of Planned Behavior}

This study uses the TPB model proposed by Ajzen [18] to investigate consumers' motivations of sustainable consumption intentions during China's Double-11 shopping festival. The TPB model has been one of the most widely used models for studying environmental behaviors [19]. Many researchers believe that the TPB model can explain consumers' sustainable consumption behavioral intentions and predict their future behaviors well [20]. The TPB model indicates that consumers' sustainable consumption intentions can best predict their future sustainable consumption behavior $[9,18]$. Research has shown that there are consistencies between people's beliefs, attitudes, and behaviors [21]. More specifically, consumers' sustainable consumption intention is an essential component of sustainable consumption behaviors [22].

The TPB model demonstrates that human intention is guided by three predictors, including attitude towards behavior, the subjective norm, and perceived behavioral control. Attitude towards behavior refers to consumers' evaluation of the performance of a particular behavior; the subjective norm is defined as the social pressure that consumers perceive when engaging in a particular behavior; 
and perceived behavioral control is defined as consumers' perceived difficulty or ease when they perform a particular behavior [9]. However, although the TPB model has been widely used to examine the motivation of sustainable consumption intentions, researchers have noticed that domain-specific factors have not been included in the model $[23,24]$. An increasing number of studies have extended the TPB model by including new constructs [25-27]. This study has also included one construct, atmosphere, along with the traditional TPB constructs (i.e., attitude towards behavior, subjective norm, and perceived behavioral control) to measure consumers' sustainable consumption intention.

\subsubsection{Environmental Concern and Attitude}

Environmental concern is defined as "the degree to which people are aware of problems regarding the environment and support efforts to solve them and or indicate the willingness to contribute personally to their solution" [28]. Studies have supported the importance of environmental concern in environmental attitudes research $[29,30]$. In general, consumers' attention towards environmental concern is positively associated with their attitude towards sustainable consumption behaviors [31]. Several studies have shown that consumers with a high level of environmental concern have a more positive attitude towards sustainable consumption $[29,32,33]$. Thus, we propose:

Hypothesis 1 (H1). Environmental concern is positively associated with the attitude towards sustainable consumption during the Double-11 shopping festival time.

\subsubsection{Environmental Concern and Subjective Norm}

The environmental concern could be considered as a crucial factor that results in a higher subjective norm [34]. Environmental concern affects subjective norm in a way that influences consumers' perceptions of pressure from their family and friends on their sustainable consumption behavior [35]. Some studies have demonstrated that compared to lowly environmentally concerned consumers, those consumers who have a higher level of environmental concern perceive stronger supports from their family and friends [35,36]. For example, Bamberg [36] examined college students' purchase decisions on green electricity products and found that environmental concern had significant effects on college students' perception of the subjective norm. Therefore, we propose that highly environmentally concerned consumers perceive a higher subjective norm from their important reference persons during the Double-11 shopping festival.

Hypothesis 2 (H2). Environmental concern is positively associated with subjective norm during the Double-11 shopping festival time.

\subsubsection{Environmental Concern and Perceived Behavioral Control}

Perceived behavioral control is defined as consumers' perceived difficulty or ease when they perform a particular behavior [9]. Peoples' behavioral control is determined by their general attitude through specific control beliefs. It reflects consumers' prior experiences and their anticipated difficulties. Consumers who think that it is difficult to perform a particular behavior might not have strong intentions, even though their attitude and subjective norm is favorable. Thus, consumers' perceived behavioral control has motivational implications for their behavior. Previous studies have shown the relationship between consumers' environmental concern and their perceived behavioral control [35]. For example, Bamberg [36] found that consumers' environmental concern can predict their confidence in their ability to perform energy conservation behaviors. Based on the above discussion, we propose:

Hypothesis 3 (H3). Environmental concern is positively associated with perceived behavioral control during the Double-11 shopping festival time. 


\subsubsection{Environmental Concern and Purchase Intention}

Environmental concern is critical to consumers' decision-making process [37]. From a theoretical perspective, the environmental concern could be treated as a type of general attitude in the TPB theory [36,38]. It represents consumers' worries, compassion, and likes toward the environment [39], which could affect their decision in all stages of the purchase process [40]. The underlying reason for this is that consumers who are highly concerned about the environment tend to behave in an environmentally friendly way [41]. Many studies have found a positive relationship between environmental concern and purchase intention of green products. For example, Irawan and Darmayanti [42] found that students with high environmental concern in Indonesian universities have more green purchase intentions. Aman et al. [43] also indicate a positive correlation between environmental concern and green product purchase intention. The positive relation between environmental concern and sustainable consumption behavior is examined not only in western countries, but also in eastern countries [44]. Thus, the increased environmental concern is positively associated with consumers' sustainable consumption behaviors, expanding the market for green products. Specifically, in our research context, consumers who have a high level of environmental concern are more likely to have higher purchase intentions for sustainable consumption during the Double-11 shopping festival. Thus, we propose:

Hypothesis 4 (H4). Environmental concern is positively associated with purchase intention for sustainable consumption during the Double-11 shopping festival time.

\subsubsection{Attitude and Purchase Intention}

In the TPB model, attitude is one of the determinants of purchase intention. As an interaction in memory between a product and the evaluation of the product, attitude can be used to discover consumers' psychological evolution of the product [21,45,46] and predict real human behavior [9]. Studies have revealed the relationships between attitude and purchase intention [47]. For example, Birgelen et al. [48] conclude that if consumers have a positive attitude towards the environment, they are likely to choose environmentally friendly beverage packaging. Han and Yoon [49] found that consumers' attitude towards sustainable consumption is positively associated with their booking intention towards green hotels. Thus, we propose:

Hypothesis 5 (H5). Attitude towards sustainable consumption is positively associated with purchase intention for sustainable consumption during the Double-11 shopping festival time.

\subsubsection{Subjective Norm and Purchase Intention}

The subjective norm is consumers' perceived social pressure that forces them to behave in a certain way to meet social expectations [9]. If a particular behavior that consumers perform meets the social expectations, consumers are likely to perform the behavior; otherwise, consumers might not perform the behavior [50]. A number of studies have indicated a positive relationship between subjective norm and sustainable consumption, such as green hotel booking intention [34,51], organic food purchase intention [52,53], and environmental conscious consumption [54,55]. Thus, we propose that the subjective norm has important effects on consumers' sustainable consumption behavior.

Hypothesis 6 (H6). Subjective norm is positively associated with purchase intention for sustainable consumption during the Double-11 shopping festival time. 


\subsubsection{Perceived Behavioral Control and Purchase Intention}

Perceived behavioral control includes two aspects. One aspect refers to the availability of resources such as money and time required for performing a behavior, and the other aspect refers to consumers' confidence in performing the behavior $[9,56]$. When consumers have both the ability and confidence to perform a particular behavior, the behavior possibly occurs [57]. Studies have reported a positive relationship between perceived behavioral control and sustainable consumption in a variety of contexts, such as green hotel booking intention [38,58], organic food purchase intention [53,59,60], and environmental conscious consumption $[54,56]$. Thus, we propose:

Hypothesis 7 (H7). Perceived behavioral control is positively associated with purchase intention for sustainable consumption during the Double-11 shopping festival time.

\subsection{Atmosphere and Sustainable Consumption}

The atmospherics of off-line stores are defined as "the conscious designing of space to create effects in buyers ... (and) the effort to design buying environments to produce specific emotional effects in the buyer that enhance his purchase probability" [61] (p. 50). The atmospherics of an off-line store mainly consist of its physical environment, such as cleanliness, music, scent, temperature, lighting, color, and display [62]. Some studies have identified the influence of off-line store atmospherics on consumer behavior, emotion, and satisfaction [63]. For example, Srinivasan and Srivastava [64] indicate that the atmospherics of off-line stores have direct effects on consumers' purchase intention through creating enjoyable experiences for consumers. Silva and Giraldi [65] found that the impressive atmospherics of off-line stores enhance consumers' satisfaction level.

Based on the definition of atmospherics proposed by Kolter [61], Dailey [66] (p. 796) defines online atmospherics as "the conscious designing of web environments to create positive effects in users in order to increase favourable consumer responses". Although online atmospheres lack some cues of off-line store atmospheres (e.g., olfactory cues), online retailers could manipulate other cues, such as color, graphics, context, layout, and music for the online atmosphere to stimulate consumers' senses and responses [67].

While online atmospherics refer to the designing of web environments that attract consumers to enter and purchase, the online atmosphere is viewed as consumers' mood or emotion conveyed by the setting [68]. The effect of the online atmosphere on consumer purchase behavior has gained increasing attention from both researchers and managers [69]. For example, Eroglu et al. [70] found that the online atmosphere influences web visitors' pleasure and arousal. Carroll [71] has suggested that online atmosphere is an important factor influencing online shopping behavior, as the online atmosphere incorporates consumers into the same virtual community. Chen et al. [72] point out that the online shopping atmosphere influences consumers' willingness to purchase.

However, although some studies have examined the effects of the atmosphere on consumer purchase behavior, few studies have empirically investigated how it influences consumers' sustainable consumption behavior [8]. To the best of our knowledge, Robinot et al. [8] are the only group to have empirically tested the relationship between atmosphere and consumers' sustainable consumption behavior; they concluded that the Christmas atmosphere does not significantly influence socially responsible purchase intention. Although Robinot et al. [8] did not find a significant relationship between the Christmas atmosphere and consumers' sustainable consumption behavior, we propose that the atmosphere during the Chinese Double-11 online shopping festival, a national shopping festival, would have a negative effect on consumers' sustainable consumption behavior.

On the one hand, festivals such as Christmas are considered as symbolic of hyper-capitalism [73]. The shopping atmosphere at festivals is marked by the "symbolic exchange," where the hedonic, aesthetic, and social considerations outweigh more environmentally sustainable concerns. Generally speaking, festivals result in the production of a great number of non-green products, which are 
condemned by environmental and anti-consumerist organizations [74]. As a period of intensified consumption, festivals thus produce a significant number of environmental issues. For example, Bryant [75] suggests that Christmas is the world's largest annual environmental disaster. Haq et al. [73] conclude that about $£ 4$ billion was spent on unwanted fits in the United Kingdom each year.

On the other hand, price promotion acts as a tempting mechanism that greatly reduces consumers' self-control resources [76]. The reduced self-control resources result in consumers' impulsive behavior [77], which is not regulated but results from unplanned and spontaneous impulses [78]. Compared to unsustainable consumption behavior, sustainable consumption behavior is less likely to be impulsive behavior because it is a more planned behavior [79]. Thus, huge price promotions offered at China's Double-11 online shopping festival weaken consumers' attitudes towards and preference for sustainable consumption but strengthen those for unsustainable consumption. Moreover, the national shopping festival atmosphere influences the subjective norm, whereas it dampens consumers' perceived pressure from others on sustainable consumption. Integrating the above discussions, we therefore propose:

Hypothesis 8 (H8). The Double-11 shopping festival atmosphere is negatively associated with consumers' attitude towards sustainable consumption.

Hypothesis 9 (H9). The Double-11 shopping festival atmosphere is negatively associated with consumers' subjective norm.

Hypothesis 10 (H10). The Double-11 shopping festival atmosphere is negatively associated with consumers' perceived behavioral control.

Hypothesis 11 (H11). The Double-11 shopping festival atmosphere is negatively associated with consumers' purchase intention for sustainable consumption.

On the basis of the discussed hypotheses, the following theoretical framework (see Figure 1) is proposed.

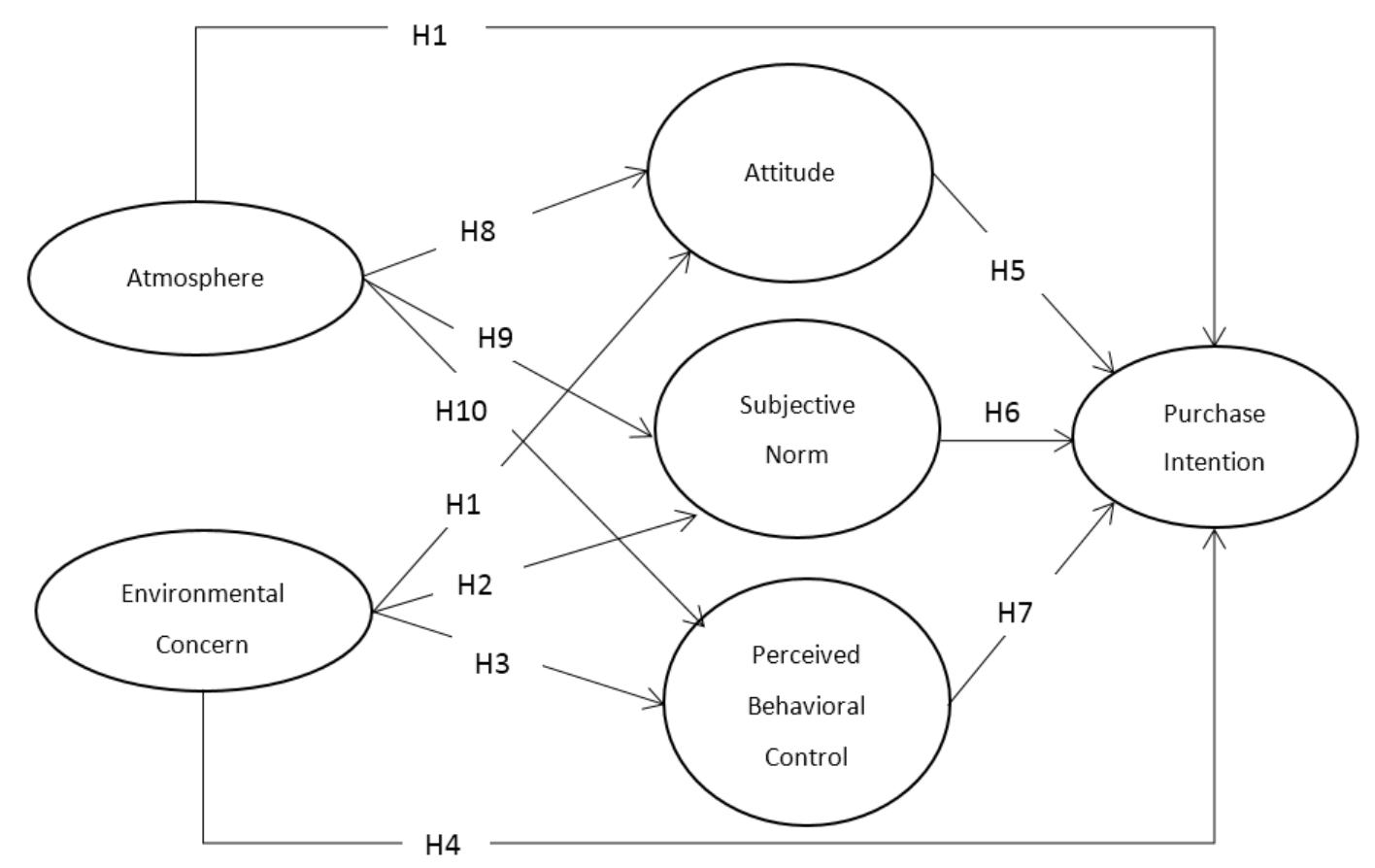

Figure 1. Proposed research framework. 


\section{Methodology}

\subsection{Sample and Data Collection}

Our hypotheses were tested empirically in an actual pre-holiday purchase context-China's Double-11 shopping festival purchase setting. According to Robinot et al.'s [8] suggestion, the survey should be conducted a month before the holiday. Thus, we surveyed on 20 October 2017 and 10 November 2017, in Shanghai, to capture consumers' real-time reactions to Double-11 shopping festival purchases. A representative stratified random sample of 450 adult consumers participated in our online survey. The participants were informed that the purpose of the survey was to examine their online shopping behavior. They were paid the equivalent of one-hour's salary based on the city's scale. In total, 404 usable responses were received, which yielded a response rate of $89.78 \%$. In total, $52.72 \%$ of the survey participants were female, and the other $47.28 \%$ were male. Table 1 displays the distribution of survey participants by gender, age, marital status, education, employment status, average online shopping frequency, and monthly household income.

Table 1. Descriptive statistics of sample characteristics $(n=404)$.

\begin{tabular}{|c|c|c|c|}
\hline Characteristics & Categories & $\mathbf{N}$ & $\%$ \\
\hline \multirow{2}{*}{ Gender } & Male & 191 & 47.28 \\
\hline & Female & 213 & 52.72 \\
\hline \multirow{6}{*}{ Age } & 18-24 years & 82 & 20.30 \\
\hline & $25-34$ years & 148 & 36.63 \\
\hline & 35-44 years & 71 & 17.57 \\
\hline & $45-54$ years & 60 & 14.85 \\
\hline & 55-64 years & 27 & 6.68 \\
\hline & 65 years or older & 16 & 3.96 \\
\hline \multirow{3}{*}{ Marital status } & Single & 129 & 31.93 \\
\hline & Married & 252 & 62.38 \\
\hline & Divorced/Widowed & 23 & 5.69 \\
\hline \multirow{5}{*}{ Education } & High school and below & 95 & 23.51 \\
\hline & Diploma & 84 & 20.79 \\
\hline & Bachelor's degree & 162 & 40.10 \\
\hline & Master's degree & 49 & 12.13 \\
\hline & Doctoral degree & 14 & 3.47 \\
\hline \multirow{6}{*}{ Employment status } & Student & 77 & 19.06 \\
\hline & Housewife & 71 & 17.57 \\
\hline & Business & 42 & 10.40 \\
\hline & Full-time job & 161 & 39.85 \\
\hline & Part-time job & 12 & 2.97 \\
\hline & Others & 41 & 10.15 \\
\hline \multirow{7}{*}{$\begin{array}{l}\text { Average online shopping } \\
\text { frequency }\end{array}$} & Once per several months & 62 & 15.35 \\
\hline & Once a month & 69 & 17.08 \\
\hline & $\begin{array}{c}\text { Around } 2-3 \text { times a } \\
\text { month }\end{array}$ & 178 & 44.06 \\
\hline & Once a week & 44 & 10.89 \\
\hline & Around 2-4 times a week & 43 & 10.64 \\
\hline & Around 5-7 times a week & 6 & 1.49 \\
\hline & Several times a day & 2 & 0.50 \\
\hline \multirow{6}{*}{$\begin{array}{l}\text { Monthly household } \\
\text { income (CNY) }\end{array}$} & Less than 5000 & 16 & 3.96 \\
\hline & $5001-10,000$ & 119 & 29.46 \\
\hline & $10,001-15,000$ & 143 & 35.40 \\
\hline & $15,001-20,000$ & 77 & 19.06 \\
\hline & $20,001-25,000$ & 28 & 6.93 \\
\hline & More than 25,000 & 21 & 5.20 \\
\hline
\end{tabular}

\subsection{Measures}

The questionnaire mainly included measures of six constructs. All measurement items were adapted or modified from previous studies and measured through a seven-point Likert scale ranging from 1 (strongly disagree) to 7 (strongly agree). All original measures were developed in English. We 
thus employed a translation and back-translation procedure [80] to make sure all the measures were translated appropriately. Specifically, we first translated all measures into Chinese and employed a bilingual reviewer to modify the translated measures. After that, another bilingual reviewer was asked to back-translate the translated measures into English and then sent the back-translated version to us for our approval.

The atmosphere was measured based on five items modified from previous studies [68,81-84], which measured the online atmosphere from four aspects: color, image display, website design, and ads. Following Robinot et al. [8], this study measured online atmosphere generally, not the atmosphere of specific webpages, given that the Double-11 shopping festival is a national shopping festival in China, which is similar to Black Friday in the United States [5]. Participants were asked to indicate the extent to which the overall atmosphere was perceived during the Double-11 Shopping Festival. Environmental concern was measured using three items based on Kilbourne and Pickett [85] and Paul et al. [35]. Attitude toward behavior was measured by five items used for the TPB $[25,26,35]$. Subjective norm was measured using three items based on previous studies $[8,86,87]$. Perceived behavioral control was measured by three items proposed by Netemeyer et al. [88] and Robinot et al. [8]. Green purchase intention was measured through five items, as suggested by Kanchanapibul et al. [89] and Paul et al. [35]. Table 2 presents the descriptive statistics of all the items, including their mean value and standard deviation.

Table 2. Descriptive statistics of questionnaire items.

\begin{tabular}{|c|c|c|}
\hline Questionnaire Items & Mean & Standard Deviation \\
\hline \multicolumn{3}{|l|}{ Environmental concern } \\
\hline EC1: Major political change is necessary to protect the natural environment & 6.10 & 1.02 \\
\hline EC2: Major social changes are necessary to protect the natural environment & 6.11 & 0.97 \\
\hline EC3: Anti-pollution laws should be enforced more strongly & 6.28 & 0.99 \\
\hline \multicolumn{3}{|l|}{ Atmosphere } \\
\hline AM1: The color on the websites is attractive. & 4.03 & 1.73 \\
\hline AM2: The color on the websites is bright & 4.42 & 1.78 \\
\hline AM3: The image display on the websites is attractive and lively & 4.34 & 1.82 \\
\hline AM4: The website design on the websites is attractive and stimulating & 4.00 & 1.72 \\
\hline $\begin{array}{l}\text { AM5: The "Double-11 Shopping Festival" ads on the websites influence my moods } \\
\text { and emotions }\end{array}$ & 4.09 & 1.76 \\
\hline \multicolumn{3}{|l|}{ Attitude } \\
\hline \multirow{2}{*}{\multicolumn{3}{|c|}{$\begin{array}{l}\text { Taking into account information related to the protection of the environment in my } \\
\text { Double- } 11 \text { purchases... }\end{array}$}} \\
\hline & & \\
\hline ATT1: is favorable & 5.71 & 1.18 \\
\hline ATT2: is a good idea & 5.95 & 1.04 \\
\hline ATT3: is a positive behavior & 6.08 & 1.02 \\
\hline ATT4: is a valuable behavior & 6.08 & 1.06 \\
\hline ATT5: is a beneficial behavior & 6.16 & 0.94 \\
\hline \multicolumn{3}{|l|}{ Subjective norm } \\
\hline $\begin{array}{l}\text { SN1: Most of the people who are important to me think that I should take into } \\
\text { account environmental information for my "Double-11 Shopping Festival" shopping }\end{array}$ & 5.02 & 1.30 \\
\hline $\begin{array}{l}\text { SN2: Most of the people who are important to me approve that I take into account } \\
\text { environmental information for my "Double-11 Shopping Festival" shopping }\end{array}$ & 5.16 & 1.25 \\
\hline $\begin{array}{l}\text { SN3: Most of the people who are important to me think that taking into account } \\
\text { environmental information for my "Double-11 Shopping Festival" shopping is a } \\
\text { good thing }\end{array}$ & 5.34 & 1.24 \\
\hline \multicolumn{3}{|l|}{ Perceived behavioral control } \\
\hline $\begin{array}{l}\text { PBC1: To me, taking into account environmental information for my Double-11 } \\
\text { shopping is easy }\end{array}$ & 4.97 & 1.39 \\
\hline $\begin{array}{l}\text { PBC2: I can, without any problem, take into account environmental information for } \\
\text { my Double- } 11 \text { shopping }\end{array}$ & 4.82 & 1.45 \\
\hline $\begin{array}{l}\text { PBC3: Taking into account environmental information for my Double-11 shopping is } \\
\text { a decision that is only up to me }\end{array}$ & 5.13 & 1.41 \\
\hline \multicolumn{3}{|l|}{ Purchase intention } \\
\hline \multicolumn{3}{|l|}{ When doing my Double-11 shopping... } \\
\hline PI1: I will consider buying products because they are less polluting in coming times & 5.40 & 1.31 \\
\hline $\begin{array}{l}\text { P12: I will consider switching to environmental friendly brands for ecological } \\
\text { reasons }\end{array}$ & 5.29 & 1.32 \\
\hline $\begin{array}{l}\text { PI3: I plan to spend more on environmental friendly products rather than } \\
\text { conventional products }\end{array}$ & 4.88 & 1.41 \\
\hline $\begin{array}{l}\text { PI4: I expect to purchase green products in the future because of its positive } \\
\text { environmental contribution }\end{array}$ & 5.12 & 1.41 \\
\hline PI5: I definitely want to purchase green products in the near future & 4.57 & 1.59 \\
\hline
\end{tabular}




\section{Results}

\subsection{Testing of Reliability and Validity of the Measurement Model}

Given the effect of non-normality (kurtosis in particular) on estimates in SEM, we first screened the observed variables for out-of-range kurtosis and skewness before testing the reliability and validity [90]. The results showed that the kurtosis values (ranging from -1.054 to 4.616 , median $=0.010$, mean $=0.854)$ were within ranges of $[-10,10]$ and the skewness values (ranging from -1.798 to 0.109 , median $=-0.683$, mean $=-0.771)$ were within ranges of $[-3,3]$, which did not show any issues with the normality assumption [91]. Second, we tested the Cronbach's alpha scores for all constructs. We noticed that atmosphere, attitude, subjective norm, and purchase intention had a very high value for Cronbach's alpha (i.e., 0.95, 0.93, 0.93, and 0.93, respectively). To reduce unnecessary redundancy, as suggested by Streiner [92], we have examined the matrix of correlations of the individual items. For those paired items that have a high correlation coefficient, we only kept one of them. Therefore, we removed AM3, AM5, ATT3, SN2, PI2, and PI4 from the original scales. The Cronbach's alpha values of the six constructs in the new scales range between 0.8 and 0.9 .

Table 3 reported the standardized factor loadings (SFLs) for each item, as well as the Cronbach's alpha scores and the composite reliability (CR) for each construct. The standardized factor loadings for each item were greater than the cut-off of 0.50 [93], ranging from 0.63 to 0.90 . The Cronbach's $\alpha$ values and composite reliabilities of the six constructs-EC, AM, ATT, SN, PBC, and PI-were greater than the threshold value of 0.7 [94]. We further examined the measurement model fit through overall confirmatory factor analysis (CFA). As presented in Table 3, the results show an acceptable fit $\left(\mathrm{x}^{2}(120)=419.60, \mathrm{x}^{2} / \mathrm{df}=3.50, p<0.001\right.$, Normed Fit Index $(\mathrm{NFI})=0.92$, Confirmatory Fit Index $(\mathrm{CFI})=0.94$, Tucker-Lewis Index $(\mathrm{TLI})=0.92$, and Root Mean Square Error of Approximation $($ RMSEA $)=0.08)$. Thus, all constructs had adequate reliability and convergent validity levels.

Table 3. Standardized factor loading, Cronbach's alpha, and composite reliability of the constructs.

\begin{tabular}{|c|c|c|c|}
\hline Questionnaire Items & Standardized Loading & Cronbach's Alpha & Composite Reliability \\
\hline \multicolumn{4}{|l|}{ Environmental concern } \\
\hline EC1 & 0.83 & \multirow{3}{*}{0.85} & \multirow{3}{*}{0.86} \\
\hline EC2 & 0.90 & & \\
\hline EC3 & 0.72 & & \\
\hline \multicolumn{4}{|l|}{ Atmosphere } \\
\hline AM1 & 0.88 & \multirow{3}{*}{0.90} & \multirow{3}{*}{0.91} \\
\hline AM2 & 0.87 & & \\
\hline AM4 & 0.88 & & \\
\hline \multicolumn{4}{|l|}{ Attitude } \\
\hline ATT1 & 0.78 & \multirow{4}{*}{0.90} & \multirow{4}{*}{0.91} \\
\hline ATT2 & 0.88 & & \\
\hline ATT4 & 0.88 & & \\
\hline ATT5 & 0.84 & & \\
\hline \multicolumn{4}{|l|}{ Subjective norm } \\
\hline SN1 & 0.88 & \multirow{2}{*}{0.87} & \multirow{2}{*}{0.87} \\
\hline SN3 & 0.87 & & \\
\hline \multicolumn{4}{|c|}{ Perceived behavioral control } \\
\hline PBC1 & 0.89 & \multirow{3}{*}{0.83} & \multirow{3}{*}{0.84} \\
\hline PBC2 & 0.85 & & \\
\hline PBC3 & 0.63 & & \\
\hline \multicolumn{4}{|l|}{ Purchase intention } \\
\hline PI1 & 0.81 & \multirow{3}{*}{0.88} & \multirow{3}{*}{0.88} \\
\hline PI3 & 0.89 & & \\
\hline PI5 & 0.84 & & \\
\hline
\end{tabular}


We then assessed discriminant validity by estimating the average variance extracted (AVE) for each construct [94]. The results presented in Table 4 show that the AVE values of all constructs are greater than the recommended level of 0.50 and the square-root values of AVEs are larger than the correlations of the respectively paired constructs. Hence, the constructs have satisfied discriminant validity levels [95].

Table 4. AVE values and inter-correlations of constructs.

\begin{tabular}{cccccccc}
\hline & AVE & EC & AM & ATT & SN & PBC & PI \\
\hline EC & 0.67 & $\mathbf{0 . 8 2}$ & & & & & \\
AM & 0.77 & 0.03 & $\mathbf{0 . 8 8}$ & & & & \\
ATT & 0.72 & $0.62^{* * *}$ & $-0.10^{* *}$ & $\mathbf{0 . 8 5}$ & & & \\
SN & 0.77 & $0.33^{* * *}$ & $-0.25^{* * *}$ & $0.49^{* * *}$ & $\mathbf{0 . 8 8}$ & & \\
PBC & 0.64 & $0.25^{* * *}$ & $-0.17^{* *}$ & $0.36^{* * *}$ & $0.45^{* * *}$ & $\mathbf{0 . 8 0}$ & \\
PI & 0.72 & $0.28^{* * *}$ & $-0.28^{* * *}$ & $0.49^{* * *}$ & $0.61^{* * *}$ & $0.61^{* * *}$ & $\mathbf{0 . 8 5}$ \\
\hline
\end{tabular}

Note: The diagonal values in bold represent the squared root of AVE of each construct, and off-diagonal elements are the correlations between constructs; ${ }^{*} p<0.05 ;{ }^{* *} p<0.01$; ${ }^{* * *} p<0.001$.

\subsection{Testing of the Structural Equation Model}

We used structural equation modeling (SEM) analysis in AMOS 19.0 to examine the proposed research model. The results are presented in Table 5. First, the structural model shows an acceptable model fit $\left(x^{2}(122)=393.21, x^{2} / d f=3.22, p<0.001, \mathrm{NFI}=0.92, \mathrm{TLI}=0.93, \mathrm{CFI}=0.95, \mathrm{RMSEA}=0.07\right)$.

Table 5. Results of the structural model.

\begin{tabular}{lccc}
\hline \multicolumn{1}{c}{ Hypothesized Path } & Estimate & $\boldsymbol{t}$-Value & Results \\
\hline $\mathrm{H} 1: \mathrm{EC} \rightarrow$ ATT & 0.62 & $13.49^{* * *}$ & Supported \\
$\mathrm{H} 2: \mathrm{EC} \rightarrow$ SN & 0.39 & $6.86^{* * *}$ & Supported \\
$\mathrm{H} 3: \mathrm{EC} \rightarrow$ PBC & 0.26 & $4.46^{* * *}$ & Supported \\
$\mathrm{H} 4: \mathrm{EC} \rightarrow$ PI & -0.09 & -1.47 & Unsupported \\
$\mathrm{H} 5: \mathrm{ATT} \rightarrow$ PI & 0.23 & $4.29^{* * *}$ & Supported \\
$\mathrm{H} 6: \mathrm{SN} \rightarrow$ PI & 0.34 & $5.79^{* * *}$ & Supported \\
$\mathrm{H} 7: \mathrm{PBC} \rightarrow$ PI & 0.46 & $-2.85^{* * *}$ & Supported \\
$\mathrm{H} 8: \mathrm{AM} \rightarrow$ ATT & -0.11 & $-5.76^{* * *}$ & Supported \\
$\mathrm{H} 9: \mathrm{AM} \rightarrow$ SN & -0.30 & $-3.74^{* * *}$ & Supported \\
$\mathrm{H} 10: \mathrm{AM} \rightarrow$ PBC & -0.21 & $-2.24^{*}$ & Supported \\
$\mathrm{H} 11: \mathrm{AM} \rightarrow$ PI & -0.10 & Supported \\
$\mathrm{x}^{2}(122)=393.21, \mathrm{x}^{2} / \mathrm{df}=3.22, p<0.001, \mathrm{NFI}=0.92, \mathrm{TLI}=0.93, \mathrm{CFI}=0.95$, RMSEA $=0.07$ \\
\hline
\end{tabular}

Note: EC = Environmental Concern; ATT = Attitude; SN = Subjective Norm; PBC = Perceived Behavioral Control; $\mathrm{PI}=$ Purchase Intention; AM $=$ Atmosphere; ${ }^{*} p<0.05 ;{ }^{* *} p<0.01$; *** $p<0.001$.

Figure 2 and Table 5 show the hypotheses testing results. In total, ten out of eleven hypotheses were supported. First, environmental concern has positive and significant effects on attitude toward behavior $(\beta=0.62, p<0.001)$, subjective norm $(\beta=0.39, p<0.001)$, and perceived behavioral control $(\beta=0.26, p<0.001)$. Thus, H1, H2, and H3 are supported. However, the path from environmental concern to purchase intention was not significant $(\beta=-0.09, \mathrm{p}=0.14)$. Thus, H4 is not supported. Second, attitude toward the behavior, subjective norm, and perceived behavioral control all have significant and positive effects on purchase intention. Therefore, H5, H6, and H7 are supported. Finally, atmosphere has negative and significant effects on attitude toward behavior $(\beta=-0.11, p<0.01)$, subjective norm $(\beta=-0.30, p<0.001)$, perceived behavioral control $(\beta=-0.21, p<0.001)$, and purchase intention $(\beta=-0.10, p<0.05)$. Hence, H8, H9, H10, and H11 are supported. 


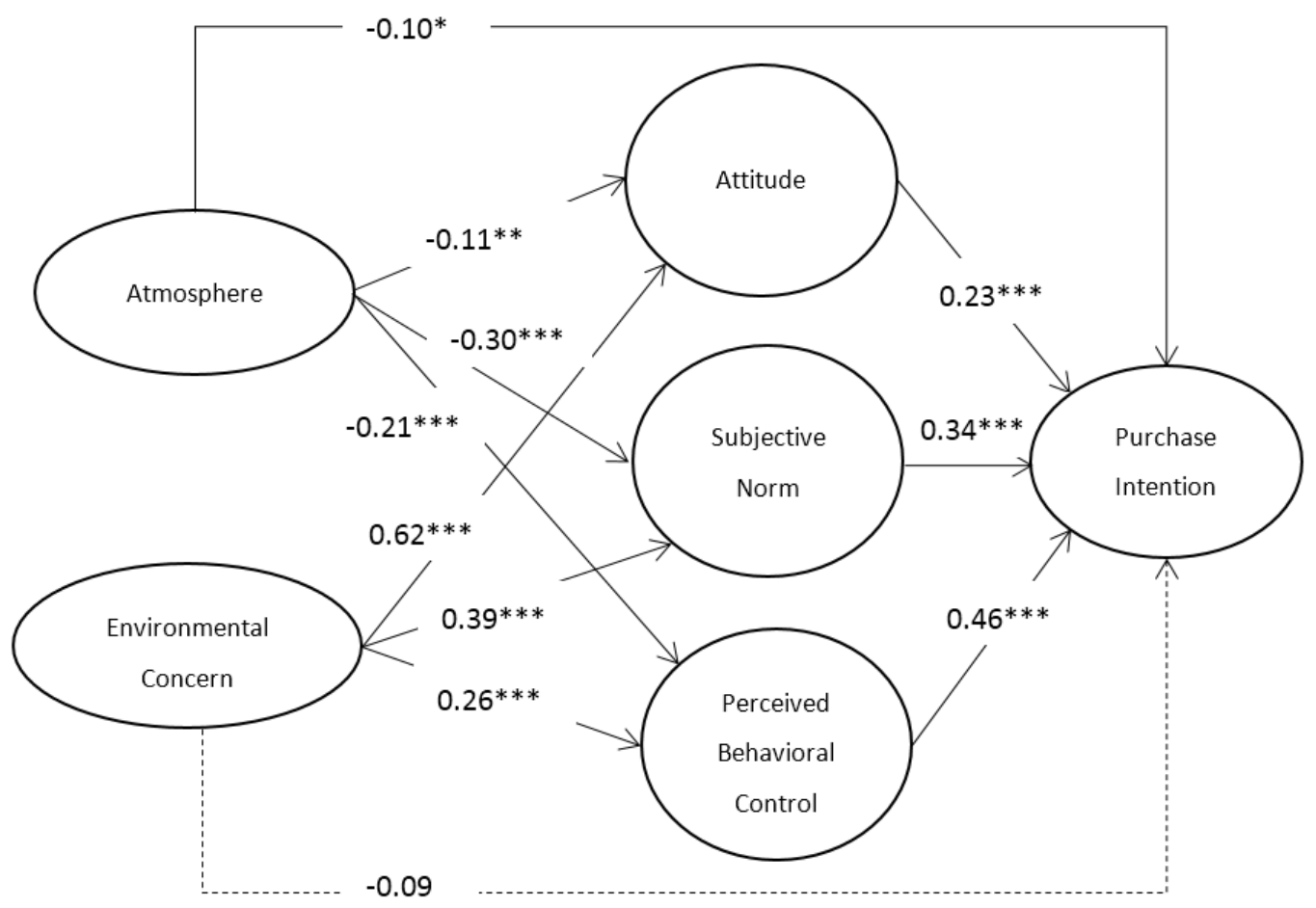

Figure 2. The results of the research model. Note: ${ }^{*} p<0.05 ;{ }^{* *} p<0.01 ;{ }^{* *} p<0.001$.

\subsection{Moderating Effects}

\subsubsection{Moderating Effects of Gender}

In this subsection, we estimate the moderating effect of consumer characteristics. First, we estimate the moderating effect of gender on purchase intention of sustainable consumption. We divided the whole sample into male $(N=191)$ and female $(N=213)$ groups and conducted a multiple group analysis to estimate the difference between the two groups. Specifically, we compared the $x^{2}$ statistic of the constraint model and the unconstraint model. If the variation of the $x^{2}$ statistic is more than 3.84, there is a significant difference between the constraint model and the unconstraint model at the $5 \%$ level. Table 6 shows the standardized and unstandardized path coefficients of the two groups. According to the result, the effect of the perceived behavioral control on purchase intention in the male group is statistically significantly stronger than the effect for the female group $(p<0.05)$. There are no significant differences between the two groups on the other path coefficients.

Table 6. Moderating effects of gender.

\begin{tabular}{|c|c|c|c|c|c|c|c|c|c|}
\hline & \multicolumn{4}{|c|}{ Male Group $(N=191)$} & \multicolumn{4}{|c|}{ Female Group $(N=213)$} & \multirow{2}{*}{ Difference btw Groups } \\
\hline & SRW & URW & S.E & C.R & SRW & URW & S.E & C.R & \\
\hline EC-PI & -0.26 & -0.30 & 0.21 & -1.46 & -0.10 & -0.15 & 0.13 & -1.09 & 0.46 \\
\hline EC-SN & 0.51 & 0.65 & 0.10 & $6.59^{* * *}$ & 0.38 & 0.56 & 0.12 & $4.79^{* * *}$ & 0.31 \\
\hline EC-PBC & 0.49 & 0.42 & 0.08 & $5.22 * * *$ & 0.22 & 0.38 & 0.13 & $3.00 * *$ & 0.09 \\
\hline ATT-PI & 0.37 & 0.45 & 0.19 & $2.38 *$ & 0.21 & 0.28 & 0.11 & $2.57 *$ & 0.61 \\
\hline AM-PI & -0.08 & -0.05 & 0.05 & -1.14 & -0.06 & -0.04 & 0.04 & -0.88 & 0.05 \\
\hline AM-ATT & -0.16 & -0.09 & 0.03 & $-2.97^{* *}$ & -0.07 & -0.04 & 0.03 & -1.13 & 1.63 \\
\hline AM-SN & -0.34 & -0.25 & 0.05 & $-4.74^{* * *}$ & -0.29 & -0.18 & 0.05 & $-3.82 * * *$ & 0.75 \\
\hline AM-PBC & -0.16 & -0.08 & 0.04 & $-2.13 *$ & -0.28 & -0.20 & 0.06 & $-3.64^{* * *}$ & 3.30 \\
\hline
\end{tabular}

Note: SRW is the standardized regression weight; URW is the unstandardized regression weight; EC = Environmental Concern; ATT $=$ Attitude; $\mathrm{SN}=$ Subjective Norm; $\mathrm{PBC}=$ Perceived Behavioral Control; $\mathrm{PI}=$ Purchase Intention; $\mathrm{AM}=$ Atmosphere; ${ }^{*} p<0.05 ;{ }^{* *} p<0.01 ;{ }^{* * *} p<0.001$. 


\subsubsection{Moderating Effects of Age}

Second, we estimate the moderating effect of age on purchase intention of sustainable consumption. We divided the whole sample into 230 juniors and 174 seniors, where 35 was used as the cut-off to divide the sample. Table 7 shows the standardized and unstandardized path coefficients of the junior and senior groups. As can be seen in Table 7, the effect of environmental concern on attitude for the junior group is weaker than that for the senior group, and this difference is statistically significant $(p<0.05)$.

Table 7. Moderating effects of age.

\begin{tabular}{|c|c|c|c|c|c|c|c|c|c|}
\hline & \multicolumn{4}{|c|}{ Junior Group $(N=230)$} & \multicolumn{4}{|c|}{ Senior Group $(N=174)$} & Difference btw Groups \\
\hline EC-PI & -0.10 & -0.13 & 0.12 & -1.12 & -0.16 & -0.19 & 0.36 & -0.52 & 0.02 \\
\hline EC-SN & 0.37 & 0.54 & 0.10 & $5.37^{* * *}$ & 0.52 & 0.58 & 0.10 & $5.85^{* * *}$ & 0.07 \\
\hline EC-PBC & 0.27 & 0.35 & 0.10 & $3.70 * * *$ & 0.44 & 0.43 & 0.09 & $4.67^{* * *}$ & 0.33 \\
\hline ATT-PI & 0.23 & 0.27 & 0.10 & $2.75^{* *}$ & 0.31 & 0.32 & 0.29 & 1.09 & 0.02 \\
\hline AM-PI & -0.08 & -0.05 & 0.04 & -1.24 & -0.11 & -0.08 & 0.05 & -1.47 & 0.11 \\
\hline AM-ATT & -0.17 & -0.09 & 0.03 & $-2.83^{* *}$ & -0.11 & -0.07 & 0.03 & $-2.17 *$ & 0.13 \\
\hline AM-SN & -0.37 & -0.27 & 0.05 & $-5.54^{* * *}$ & -0.23 & -0.16 & 0.05 & $-2.90^{* *}$ & 2.17 \\
\hline AM-PBC & -0.28 & -0.18 & 0.05 & $-3.92^{* * *}$ & -0.18 & -0.10 & 0.05 & $-2.15^{*}$ & 1.37 \\
\hline
\end{tabular}

Note: SRW is the standardized regression weight; URW is the unstandardized regression weight; $\mathrm{EC}=$ Environmental Concern; ATT = Attitude; $\mathrm{SN}=$ Subjective Norm; PBC $=$ Perceived Behavioral Control; $\mathrm{PI}=$ Purchase Intention; AM $=$ Atmosphere; ${ }^{*} p<0.05 ;{ }^{* *} p<0.01 ;{ }^{* * *} p<0.001$.

\subsubsection{Moderating Effects of Online Shopping Frequency}

Third, we estimate the moderating effect of online shopping frequency on purchase intention of sustainable consumption. Based on participants' online shopping frequency, we divided the whole sample into two groups-those who shopped online frequently $(N=273)$ and those who did not $(N=131)$. The results in Table 8 show that the effect of the atmosphere on subjective norm in the high-frequency group is statistically significantly weaker than the effect for the low-frequency group $(p<0.01)$.

Table 8. Moderating effects of online shopping frequency.

\begin{tabular}{|c|c|c|c|c|c|c|c|c|c|}
\hline & \multicolumn{4}{|c|}{ High-Frequency Group $(N=273)$} & \multicolumn{4}{|c|}{ Low-Frequency Group $(N=131)$} & \multirow{2}{*}{ Difference btw Groups } \\
\hline & SRW & URW & S.E & C.R & SRW & URW & S.E & C.R & \\
\hline EC-PI & -0.12 & -0.16 & 0.12 & -1.35 & -0.19 & -0.26 & 0.18 & -1.42 & 0.24 \\
\hline EC-SN & 0.46 & 0.59 & 0.10 & $6.25 * * *$ & 0.38 & 0.59 & 0.14 & $4.12^{* * *}$ & 0.00 \\
\hline EC-PBC & 0.33 & 0.45 & 0.10 & $4.68 * * *$ & 0.28 & 0.30 & 0.11 & $2.75 * *$ & 0.98 \\
\hline ATT-PI & 0.22 & 0.26 & 0.09 & $2.79 * *$ & 0.36 & 0.20 & 0.17 & $3.05^{* *}$ & 1.49 \\
\hline AM-PI & -0.03 & -0.02 & 0.04 & -0.52 & -0.20 & -0.12 & 0.06 & $-2.22 *$ & 2.70 \\
\hline AM-ATT & -0.07 & -0.04 & 0.03 & -1.36 & -0.15 & -0.07 & 0.03 & $-2.12 *$ & 0.36 \\
\hline AM-SN & -0.18 & -0.12 & 0.04 & $-2.73^{* *}$ & -0.47 & -0.33 & 0.06 & $-5.63^{* * *}$ & $7.92 * *$ \\
\hline AM-PBC & -0.12 & -0.08 & 0.05 & -1.77 & -0.40 & -0.19 & 0.05 & $-3.93^{* * *}$ & 2.68 \\
\hline
\end{tabular}

Note: SRW is the standardized regression weight; URW is the unstandardized regression weight; EC = Environmental Concern; ATT = Attitude; $\mathrm{SN}=$ Subjective Norm; $\mathrm{PBC}=$ Perceived Behavioral Control; $\mathrm{PI}=$ Purchase Intention; $\mathrm{AM}=$ Atmosphere; ${ }^{*} p<0.05 ;{ }^{* *} p<0.01 ;{ }^{* * *} p<0.001$.

\subsubsection{Moderating Effects of Monthly Household Income}

Lastly, we estimate the moderating effect of monthly household income on purchase intention of sustainable consumption. Based on participants' monthly household income, we divided the whole sample into the low-income group $(N=278)$ and the high-income group $(N=126)$. Table 9 shows the standardized and unstandardized path coefficients of the two groups. The results show that the 
effect of the atmosphere on subjective norm differs significantly between the two groups. Specifically, the effect of the atmosphere on subjective norm in the high-income group is statistically significantly stronger than that for the low-income group $(p<0.05)$. Besides, the effect of environmental concern on subjective norm in the high-income group is statistically significantly stronger than that for the low-income group $(p<0.05)$.

Table 9. Moderating effects of monthly household income.

\begin{tabular}{|c|c|c|c|c|c|c|c|c|c|}
\hline & \multicolumn{4}{|c|}{ Low-Income Group $(N=278)$} & \multicolumn{4}{|c|}{ High-Income Group $(N=126)$} & Difference btw Groups \\
\hline EC-PI & -0.16 & -0.21 & 0.11 & -1.86 & -0.06 & -0.09 & 0.21 & -0.42 & 0.33 \\
\hline EC-SN & 0.36 & 0.49 & 0.10 & $5.13^{* * *}$ & 0.55 & 0.84 & 0.15 & $5.74^{* * *}$ & $3.92 *$ \\
\hline EC-PBC & 0.20 & 0.28 & 0.10 & $2.90 * *$ & 0.56 & 0.53 & 0.11 & $4.67^{* * *}$ & 2.83 \\
\hline ATT-PI & 0.27 & 0.33 & 0.10 & $3.44^{* * *}$ & 0.29 & 0.38 & 0.15 & $2.59 *$ & 0.06 \\
\hline AM-PI & -0.12 & -0.07 & 0.04 & $-2.10 *$ & -0.02 & -0.01 & 0.07 & -0.19 & 0.73 \\
\hline AM-ATT & -0.06 & -0.03 & 0.03 & -1.22 & -0.18 & -0.10 & 0.04 & $-2.51 * *$ & 1.91 \\
\hline AM-SN & -0.23 & -0.15 & 0.04 & $-3.57^{* * *}$ & -0.44 & -0.34 & 0.06 & $-5.36^{* * *}$ & $5.89 *$ \\
\hline AM-PBC & -0.13 & -0.08 & 0.04 & -1.87 & -0.42 & -0.20 & 0.05 & $-4.26^{* * *}$ & 3.27 \\
\hline
\end{tabular}

Note: SRW is the standardized regression weight; URW is the unstandardized regression weight; EC = Environmental Concern; ATT = Attitude; $\mathrm{SN}=$ Subjective Norm; PBC = Perceived Behavioral Control; PI = Purchase Intention; $\mathrm{AM}=$ Atmosphere; ${ }^{*} p<0.05 ;{ }^{* *} p<0.01 ;{ }^{* * *} p<0.001$.

\section{Discussion and Conclusions}

\subsection{Discussion}

While a great number of studies have examined Chinese people's sustainable consumption behaviors for regular purchases, they have ignored extraordinary situations. Since shopping atmosphere during festive periods could affect consumers' sustainable consumption behaviors [8], it is necessary to investigate Chinese people's sustainable consumption behaviors during the Double-11 shopping festival, a national shopping festival in China [5]. In this study, we examined the effect of the atmosphere, specifically China's Double-11 Shopping Festival atmosphere, on consumers' sustainable consumption behavior.

This study contributes to the literature in several ways. First, this study contributes to the literature on atmosphere. Some studies have investigated the effect of atmospheric variables on consumer behaviors [10]. However, very few studies have examined the effects of specific atmospheric variables on consumers' sustainable consumption [8]. To the best of our knowledge, there is no research that has directly investigated the effect of the atmosphere on customer sustainable consumption during China's Double 11 shopping festival, except the research by Robinot et al. [8], who investigated the consumers' purchase intentions toward green products during Christmas. Consistent with Robinot et al.'s [8] results, our findings show the importance of considering different consumption contexts when examining consumers' sustainable consumption behavior. Thus, our study contributes to the domain of atmosphere through greater understanding of consumers' behavior at China's Double-11 shopping festival.

Second, this study contributes to the TPB model [9]. The TPB model has been one of the most widely used models for examining environmental behaviors [19]. Some studies have applied the TPB model to a variety of sustainable consumptions, for example, green hotels [34,51] and organic food purchases [52,53]. This current study investigated an extended framework of the TPB model, where environmental concern and atmosphere were antecedents of consumers' attitude toward sustainable consumption, subjective norm, and perceived behavioral control. Our results confirm the suitable application of the TPB model in our context and indicate that consumers' purchase intention toward sustainable consumption during China's Double-11 shopping festival could be predicted by environmental concern and atmosphere. 
Moreover, the strength of the relationships between attitude, subjective norm, perceived behavioral control, and purchase intention is different from results found in previous studies $[51,96]$. Previous studies reported that attitude was the strongest predictor of consumers' sustainable consumption intention. However, perceived behavioral control served as the strongest predictor in this study. This illustrates the importance of perceived behavioral control in the domain of consumers' sustainable consumption during China's Double-11 shopping festival.

This study also makes some managerial contributions. Although our results indicate a negative relationship between atmosphere and purchase intention of sustainable consumption, it is not appropriate to suggest adjusting the shopping festival atmosphere to increase consumers' sustainable consumption purchases as most Chinese people are quite fond of the annual festivities. However, our results indicate that increasing consumers' sustainable consumption requires improving consumers' attitude, subjective norm, and perceived behavioral control. For example, communication campaigns that show consumers the personal, social, and environmental importance of sustainable consumption could be conducted to improve consumers' attitude toward sustainable consumption. We can also achieve increased consumers' sustainable consumption by changing subjective norms. It can be induced, for instance, through delivering a social and community feel to consumers [8]. This study provides managerial implications for practitioners by showing that the effects of atmosphere differ across age, online shopping frequency, and monthly household income.

This study has some limitations that provide directions for future research. First, we relied on consumers' self-reported measures to examine their future consumption behaviors at China's Double-11 shopping festival rather than their actual consumption behaviors during the festival time. Future research could utilize data from other sources, such as secondary data or lab experiment data. Second, we only examined the effects of the atmosphere at China's Double-11 shopping festival on consumers' sustainable consumption behaviors. Future research could investigate whether the effects are reproducible in other exceptional situations. Third, considering that those previous studies on atmosphere $[8,68,83]$ did not examine the stability of measures and that we were not able to collect the second dataset under a similar shopping atmosphere to conduct test-retest analysis, we thus did not report the examination of the stability of measures in the study. This could be evaluated in future research. Fourth, the sample sizes of the low-frequency group and the high-income group were relatively small. Lastly, although our sampling method was able to minimize sampling bias, future research could employ different sampling methods to check the robustness of our findings.

\subsection{Conclusions}

The results of this study reveal several important findings. First, the atmosphere specific to China's Double-11 shopping festival was negatively associated with consumers' purchase intention toward sustainable consumption. The negative relationship was partially mediated by consumers' attitude toward sustainable consumption, subjective norm, and perceived behavioral control.

Second, the results show that the environmental concern was positively and significantly associated with consumers' attitude toward sustainable consumption, subjective norm, and perceived behavioral control, but not with purchase intention. On the other hand, consumers' attitude, subjective norm, and perceived behavioral control significantly influenced the purchase intention toward sustainable consumption. Thus, the positive relationship between the environmental concern and purchase intention toward sustainable consumption during China's Double- 11 shopping festival was fully mediated by consumers' attitude toward sustainable consumption at the festival time, subjective norm, and perceived behavioral control.

Third, this study investigated the moderating effect of consumer characteristics. We found that the effect of the perceived behavioral control on purchase intention in the male group was statistically significantly stronger than the effect for the female group. The effect of environmental concern on attitude for the junior group was significantly weaker than that for the senior group. The effect of the atmosphere on subjective norm in the high-frequency group and the low-income group was 
statistically significantly weaker than the effect for the low-frequency group and the high-income group, respectively. Furthermore, the effect of environmental concern on subjective norm in the high-income group is statistically significantly stronger than that for the low-income group.

Author Contributions: Conceptualization, S.Y. and L.L.; Methodology, L.L. and J.M.Z.; Formal Analysis, L.L.; Investigation, L.L.; Writing-Original Draft Preparation, S.Y. and L.L.; Writing-Review \& Editing, J.M.Z.; Project Administration, S.Y.; Funding Acquisition, S.Y.

Acknowledgments: We acknowledge the financial support received from the National Science Foundation in China (No. 71602026) and the Fundamental Research Funds for the Central Universities in China.

Conflicts of Interest: The authors declare no conflict of interest.

\section{References}

1. Xiao, C.; Dunlap, R.E.; Hong, D. The Nature and Bases of Environmental Concern among Chinese Citizens. Soc. Sci. Q. 2013, 94, 672-690. [CrossRef]

2. Peattie, K. Green Consumption: Behavior and Norms. Annu. Rev. Environ. Resour. 2010, 35, $195-228$. [CrossRef]

3. Vassallo, M.; Scalvedi, M.L.; Saba, A. Investigating psychosocial determinants in influencing sustainable food consumption in Italy. Int. J. Consum. Stud. 2016, 40, 422-434. [CrossRef]

4. Big Data on 2016 double-11 Online Shopping. Available online: http://www.sohu.com/a/118821165_470031 (accessed on 28 May 2018). (In Chinese)

5. Meng, B.; Huang, Y. Patriarchal capitalism with Chinese characteristics: Gendered discourse of 'Double Eleven' shopping festival. Cult. Stud. 2017, 31, 659-684. [CrossRef]

6. Akram, U.; Hui, P.; Khan, M.K.; Hashim, M.; Qiu, Y.; Zhang, Y. Online Impulse Buying on "Double Eleven" Shopping Festival: An Empirical Investigation of Utilitarian and Hedonic Motivations. In Proceedings of the Eleventh International Conference on Management Science and Engineering Management, Kanazawa, Japan, 28-31 July 2017; (ICMSEM 2017) Lecture Notes on Multidisciplinary Industrial Engineering; Xu, J., Gen, M., Hajiyev, A., Cooke, F., Eds.; Springer: Cham, Switzerland, 2018.

7. Farbotko, C.; Head, L. Gifts, sustainable consumption and giving up green anxieties at Christmas. Geoforum 2013, 50, 88-96. [CrossRef]

8. Robinot, E.; Ertz, M.; Durif, F. Jingle Bells or 'Green' Bells? The Impact of Socially Responsible Consumption Principles upon Consumer Behavior at Christmas Time. Int. J. Consum. Stud. 2017, 41, 605-617. [CrossRef]

9. Ajzen, I. Theories of cognitive self-regulation the theory of planned behavior. Organ. Behav. Hum. Decis. Process. 1991, 50, 179-211. [CrossRef]

10. Baker, J.; Parasuraman, A.; Grewal, D.; Voss, G. The Influence of Multiple Store Environment Cues on Perceived Merchandise Value and Patronage Intentions. J. Mark. 2002, 66, 120-141. [CrossRef]

11. Banbury, C.; Stinerock, R.; Subrahmanyan, S. Sustainable consumption: Introspecting across multiple lived cultures. J. Bus. Res. 2012, 65, 497-503. [CrossRef]

12. Roman, T.; Bostan, I.; Manolică, A.; Mitrica, I. Profile of Green Consumers in Romania in Light of Sustainability Challenges and Opportunities. Sustainability 2015, 7, 6394-6411. [CrossRef]

13. Phipps, M.; Ozanne, L.K.; Luchs, M.G.; Subrahmanyan, S.; Kapitan, S.; Catlin, J.R.; Gau, R.; Naylor, R.W.; Rose, R.L.; Simpson, B.; et al. Understanding the inherent complexity of sustainable consumption: A social cognitive framework. J. Bus. Res. 2013, 66, 1227-1234. [CrossRef]

14. Prothero, A.; Dobscha, S.; Freund, J.; Kilbourne, W.; Luchs, M.; Ozanne, L.; Thøgersen, J. Sustainable Consumption: Opportunities for Consumer Research and Public Policy. J. Public Policy Mark. 2011, 30, 31-38. [CrossRef]

15. Bonini, S.M.; Oppenheim, J.M. Cultivating the green consumer. Stanf. Soc. Innov. Rev. 2008, 6, 56-61.

16. Chen, A.; Peng, N. Green hotel knowledge and tourists' staying behavior. Ann. Tour. Res. 2012, 39, $2211-2216$. [CrossRef]

17. Mcspirit, K. Sustainable consumption: Patagonia's buy less, but buy better. Corp. Environ. Strategy 1998, 5, 32-40. [CrossRef]

18. Ajzen, I. From intentions to actions: A theory of planned behavior. In Action Control; Kuhl, J., Beckmann, J., Eds.; Springer: Berlin/Heidelberg, Germany, 1985; pp. 11-39. 
19. Fielding, K.S.; Mcdonald, R.; Louis, W.R. Theory of planned behaviour, identity and intentions to engage in environmental activism. J. Environ. Psychol. 2008, 28, 318-326. [CrossRef]

20. Mannetti, L.; Pierro, A.; Livi, S. Recycling: Planned and self-expressive behaviour. J. Environ. Psychol. 2004, 24, 227-236. [CrossRef]

21. Eagly, A.H.; Chaiken, S. Attitude strength, attitude structure, and resistance to change. Attitude Strength Anteced. Conseq. 1995, 4, 413-432.

22. Rezai, G.; Teng, P.K.; Mohamed, Z.; Shamsudin, M.N. Consumers' Awareness and Consumption Intention towards Green Foods. Afr. J. Bus. Manag. 2012, 6, 4496.

23. Armitage, C.J.; Conner, M. Efficacy of the theory of planned behaviour: A meta-analytic review. Br. J. Soc. Psychol. 2001, 40, 471-499. [CrossRef] [PubMed]

24. Donald, I.J.; Cooper, S.R.; Conchie, S.M. An extended theory of planned behavior model of the psychological factors affecting commuters' transport mode use. J. Environ. Psychol. 2014, 40, 39-48. [CrossRef]

25. Jang, S.Y.; Chung, J.Y.; Kim, Y.G. Effects of environmentally friendly perceptions on customers' intentions to visit environmentally friendly restaurants: An extended theory of planned behavior. Asia Pac. J. Tour. Res. 2015, 20, 599-618. [CrossRef]

26. Maichum, K.; Parichatnon, S.; Peng, K.C. Application of the Extended Theory of Planned Behavior Model to Investigate Purchase Intention of Green Products among Thai Consumers. Sustainability 2016, 8, 1077. [CrossRef]

27. Read, D.L.; Brown, R.F.; Thorsteinsson, E.B.; Price, I. The theory of planned behavior as a model for predicting public opposition to wind farm developments. J. Environ. Psychol. 2013, 36, 70-76. [CrossRef]

28. Dunlap, R.; Jones, R. Environmental Concern: Conceptual and Measurement Issues. In Handbook of Environmental Sociology; Greenwood: London, UK, 2002.

29. Hanson, C.B. Environmental concern, attitude toward green corporate practices, and green consumer behavior in the United States and Canada. ASBBS E J. 2013, 9, 62.

30. Yadav, R.; Pathak, G.S. Young consumers' intention towards buying green products in a developing nation: Extending the theory of planned behavior. J. Clean. Prod. 2016, 135, 732-739. [CrossRef]

31. Doorn, J.V.; Verhoef, P.C. Willingness to pay for organic products: Differences between virtue and vice foods. Int. J. Res. Mark. 2011, 28, 167-180. [CrossRef]

32. Kim, Y.; Choi, S.M. Antecedents of green purchase behavior: An examination of collectivism, environmental concern, and perceived consumer effectiveness. Adv. Consum. Res. 2005, 32, 592-599.

33. Mostafa, M.M. A Hierarchical Analysis of the Green Consciousness of the Egyptian Consumer. Psychol. Mark. 2007, 24, 445-473. [CrossRef]

34. Chen, M.F.; Tung, P.J. Developing an extended Theory of Planned Behaviour model to predict consumers' intention to visit green hotels. Int. J. Hosp. Manag. 2014, 36, 221-230. [CrossRef]

35. Paul, J.; Modi, A.; Patel, J. Predicting green product consumption using theory of planned behavior and reasoned action. J. Retail. Consum. Serv. 2016, 29, 123-134. [CrossRef]

36. Bamberg, S. How does environmental concern influence specific environmentally related behaviors? A new answer to an old question. J. Environ. Psychol. 2003, 23, 21-32. [CrossRef]

37. Diamantopoulos, A.; Schlegelmilch, B.B.; Sinkovics, R.R.; Bohlen, G.M. Can socio-demographics still play a role in profiling green consumers? A review of the evidence and an empirical investigation. J. Bus. Res. 2003, 56, 465-480. [CrossRef]

38. Chang, L.; Tsai, C.; Yeh, S. Evaluation of green hotel guests' behavioral intention. In Advances in Hospitality and Leisure; Chen, J.S., Ed.; Emerald Group Publishing Limited: Bingley, UK, 2014; pp. 75-89.

39. Yeung, S.P. Teaching approaches in geography and students' environmental attitudes. Environmentalist 2005, 24, 101-117. [CrossRef]

40. Rex, E.; Baumann, H. Beyond ecolabels: What green marketing can learn from conventional marketing. J. Clean. Prod. 2007, 15, 567-576. [CrossRef]

41. Czap, N.V.; Czap, H.J. An experimental investigation of revealed environmental concern. Ecol. Econ. 2010, 69, 2033-2041. [CrossRef]

42. Irawan, R.; Darmayanti, D. The influence factors of green purchasing behavior: A study of university students in Jakarta. In Proceedings of the 6th Asian Business Research Conference, Bangkok, Thailand, 8-10 April 2012; pp. 1-11. 
43. Aman, A.L.; Harun, A.; Hussein, Z. The influence of environmental knowledge and concern on green purchase intention the role of attitude as a mediating variable. Br. J. Arts Soc. Sci. 2012, 7, 145-167.

44. None, I.; Datta, S.K. Pro-environmental Concern Influencing Green Buying: A Study on Indian Consumer. Int. J. Bus. Manag. 2011, 6, 6. [CrossRef]

45. Bonne, K.; Vermeir, I.; Bergeaud-Blackler, F.; Verbeke, W. Determinants of halal meat consumption in france. Br. Food J. 2007, 109, 367-386. [CrossRef]

46. Schiffman, L.G.; Kanuk, L.L. Purchasing Behavior; Pearson Prentice Hall: Upper Saddle River, NJ, USA, 2007.

47. Kloeckner, C.A.; Bloebaum, A. A comprehensive action determination model: Toward a broader understanding of ecological behaviour using the example of travel mode choice. J. Environ. Psychol. 2010, 30, 574-586. [CrossRef]

48. Birgelen, M.; Semeijn, J.; Keicher, M. Packaging and Pro-environmental Consumption Behaviour: Investigating purchase and disposal decisions for beverages. Environ. Behav. 2009, 41, 125-146. [CrossRef]

49. Han, H.; Yoon, H. Hotel customers' environmentally responsible behavioral intention: Impact of key constructs on decision in green consumerism. Int. J. Hosp. Manag. 2015, 45, 22-33. [CrossRef]

50. Shah Alam, S.; Mohamed Sayuti, N. Applying the theory of planned behavior (TPB) in halal food purchasing. Int. J. Commer. Manag. 2011, 21, 8-20. [CrossRef]

51. Han, H.; Hsu, L.T.J.; Sheu, C. Application of the theory of planned behavior to green hotel choice: Testing the effect of environmental friendly activities. Tour. Manag. 2010, 31, 325-334. [CrossRef]

52. Dean, M.; Raats, M.M.; Shepherd, R. The role of self-identity, past behaviour and their interaction in predicting intention to purchase fresh and processed organic food. J. Appl. Soc. Psychol. 2012, 42, 669-688. [CrossRef]

53. Ha, H.Y.; Janda, S. Predicting consumer intentions to purchase energy-efficient products. J. Consum. Mark. 2012, 29, 461-469. [CrossRef]

54. Moser, A.K. Thinking green, buying green? Drivers of pro-environmental purchasing behavior. J. Consum. Mark. 2015, 32, 167-175. [CrossRef]

55. Tsarenko, Y.; Ferraro, C.; Sands, S.; Mclead, C. Environmentally conscious consumption: The role of retailers and peers as external influences. J. Retail. Consum. Serv. 2013, 20, 302-310. [CrossRef]

56. Taylor, S.; Todd, P. Decomposition and crossover effects in the theory of planned behavior: A study of consumer adoption intentions. Int. J. Res. Mark. 1995, 12, 137-155. [CrossRef]

57. Zhou, Y.; Thøgersen, J.; Ruan, Y.; Huang, G. The moderating role of human values planned behaviour: The case of chinese consumers' intention to buy organic food. J. Consum. Mark. 2013, 30, 335-344. [CrossRef]

58. Teng, Y.M.; Wu, K.S.; Liu, H.H. Integrating altruism and the theory of planned behaviour to predict patronage intention of a green hotel. J. Hosp. Tour. Res. 2014, 39, 299-315. [CrossRef]

59. Tarkiainen, A.; Sundqvist, S. Subjective norms, attitudes and intentions of Finnish consumers in buying organic food. Br. Food J. 2005, 107, 808-822. [CrossRef]

60. Thøgersen, J. Consumer decision making with regard to organic food products. In Traditional Food Production Facing Sustainability: A European Challenge; Vaz, M.T.D.N., Vaz, P., Nijkamp, P., Rastoin, J.L., Eds.; Ashgate: Farnham, UK, 2007.

61. Kotler, P. Atmospherics as a marketing tool. J. Retail. 1974, 49, 48-64.

62. Hussain, R.; Ali, M. Effect of store atmosphere on consumer purchase intention. Int. J. Mark. Stud. 2015, 7, 35-43.

63. Russell, J.A.; Mehrabian, A. Approach-avoidance and affiliation as functions of the emotion-eliciting quality of an environment. Environ. Behav. 1978, 10, 355-387. [CrossRef]

64. Srinivasan, S.R.; Srivastava, R.K. Creating the futuristic retail experience through experiential marketing: Is it possible? An exploratory study. J. Retail Leis. Prop. 2010, 9, 193-199. [CrossRef]

65. Silva, T.S.; Giraldi, J.D.M.E. The influence of store image on customer satisfaction: A case study of a shoe store. BBR Braz. Bus. Rev. 2010, 7, 60-77. [CrossRef]

66. Dailey, L. Navigational web atmospherics: Explaining the influence of restrictive navigation cues. J. Bus. Res. 2004, 57, 795-803. [CrossRef]

67. Milliman, R.E.; Fugate, D.L. Atmospherics as an emerging influence in the design of exchange environments. J. Mark. Manag. 1993, 3, 66-74.

68. Wu, W.; Lee, C.; Fu, C.; Wang, H. How can online store layout design and atmosphere influence consumer shopping intention on a website? Int. J. Retail Distrib. Manag. 2014, 42, 4-24. [CrossRef] 
69. Davis, L.; Wang, S.; Lindridge, A. Culture influences on emotional responses to on-line store atmospheric cues. J. Bus. Res. 2007, 37, 2. [CrossRef]

70. Eroglu, S.A.; Machleit, K.A.; Davis, L.M. Empirical testing of a model of online store atmospherics and shopper responses. Psychol. Mark. 2003, 20, 139-150. [CrossRef]

71. Carroll, M. "How Retailers Can Replicate the 'magic' of the Apple Store... online", Forbes. Available online: www.forbes.com/sites/matthewcarroll/2012/06/26/how-retailers-can-replicate-the-magic-of-theapple-store-online (accessed on 3 April 2013).

72. Chen, Z.; Ling, K.C.; Ying, G.X.; Meng, T.C. Antecedents of online customer satisfaction in China. Int. Bus. Manag. 2012, 6, 168-175.

73. Haq, G.; Owen, A.; Dawkins, E.; Barrett, J. The Carbon Cost of Christmas; Stockholm Environment Institute: Stockholm, Sweden, 2007.

74. Hancock, P.; Rehn, A. Organizing Christmas. Organization 2011, 18, 737-745. [CrossRef]

75. Bryant, R.L. Peering into the abyss: Environment, research and absurdity in the 'Age of Stupid'. In The International Handbook of Environmental Sociology, 2nd ed.; Redclift, M., Woodgate, G., Eds.; Edward Elgar: Cheltenham, UK, 2010; pp. 179-188.

76. Yan, J.; Tian, K.; Heravi, S.; Morgan, P. The vices and virtues of consumption choices: Price promotion and consumer decision making. Mark. Lett. 2017, 28, 461-475. [CrossRef]

77. Wertenbroch, K. Consumption self-control by rationing purchase quantities of virtue and vice. Mark. Sci. 1998, 17, 317-337. [CrossRef]

78. Baumeister, R.F. Yielding to temptation: Self-control failure, impulsive purchasing, and consumer behavior. J. Consum. Res. 2002, 28, 670-676. [CrossRef]

79. Thomas, M.; Desai, K.K.; Seenivasan, S. How credit card payments increase unhealthy food purchases: Visceral regulation of vices. J. Consum. Res. 2011, 38, 126-139. [CrossRef]

80. Brislin, R.W. The wording and translation of research instruments. Field Methods Cross-Cult. Res. 1986, 8 , 137-164.

81. Dickson, J.; Albaum, G. A method for developing tailormade semantic differentials for specific marketing content areas. J. Mark. Res. 1977, 14, 87. [CrossRef]

82. Manganari, E.; Siomkos, G.; Vrechopoulos, A. Store atmosphere in web retailing. Eur. J. Mark. 2009, 43, 1140-1153. [CrossRef]

83. Mummalaneni, V. An empirical investigation of Web site characteristics, consumer emotional states and on-line shopping behaviors. J. Bus. Res. 2005, 58, 526-532. [CrossRef]

84. Sherman, E.; Mathur, A.; Smith, R. Store environment and consumer purchase behavior: Mediating role of consumer emotions. Psychol. Mark. 1997, 14, 361-378. [CrossRef]

85. Kilbourne, W.; Pickett, G. How materialism affects environmental beliefs, concern, and environmentally responsible behavior. J. Bus. Res. 2008, 61, 885-893. [CrossRef]

86. Knussen, C.; Yule, F.; Mackenzie, J.; Wells, M. An analysis of intentions to recycle household waste: The roles of past behaviour, perceived habit, and perceived lack of facilities. J. Environ. Psychol. 2004, 24, 237-246. [CrossRef]

87. Tonglet, M.; Phillips, P.S.; Read, A.D. Using the Theory of Planned Behaviour to investigate the determinants of recycling behaviour: A case study from Brixworth, UK. Resour. Conserv. Recycl. 2004, 41, 191-214. [CrossRef]

88. Netemeyer, R.; Burton, S.; Johnston, M. A Comparison of Two Models for the Prediction of Volitional and Goal-Directed Behaviors: A Confirmatory Analysis Approach. Soc. Psychol. Q. 1991, 54, 87. [CrossRef]

89. Kanchanapibul, M.; Lacka, E.; Wang, X.; Chan, H.K. An empirical investigation of green purchase behaviour among the young generation. J. Clean. Prod. 2014, 66, 528-536. [CrossRef]

90. Dawkins, C.E. A Test of Labor Union Social Responsibility: Effects on Union Member Attachment. Bus. Soc. 2016, 55, 214-245. [CrossRef]

91. David, P.; Kline, S.; Yang, D. Corporate social responsibility practices, corporate identity, and purchase intention: A dual-process model. J. Public Relat. Res. 2005, 17, 291-313. [CrossRef]

92. Streiner, D. Starting at the Beginning: An Introduction to Coefficient Alpha and Internal Consistency. J. Personal. Assess. 2003, 80, 99-103. [CrossRef] [PubMed]

93. Hair, J.F.; Black, W.C.; Babin, B.J.; Anderson, R.E. Multivariate Data Analysis: A Global Perspective, 7th ed.; Prentice Hall: Upper Saddle River, NJ, USA, 2010. 
94. Mackenzie, S.B.; Podsakoff, P.M.; Podsakoff, N.P. Construct Measurement and Validation Procedures in MIS and Behavioral Research: Integrating New and Existing Techniques. MIS Q. 2011, 35, 293-334. [CrossRef]

95. Bagozzi, R.P.; Yi, Y. On the evaluation of structural equation models. J. Acad. Mark. Sci. 1988, 16, 74-92. [CrossRef]

96. De Groot, J.; Steg, L. Value orientations and environmental beliefs in five countries: Validity of an instrument to measure egoistic, altruistic and biospheric value orientations. J. Cross Cult. Psychol. 2007, 38, 318-332. [CrossRef]

(c) (c) 2018 by the authors. Licensee MDPI, Basel, Switzerland. This article is an open access article distributed under the terms and conditions of the Creative Commons Attribution (CC BY) license (http:/ / creativecommons.org/licenses/by/4.0/). 